\title{
DWIE METAFORY POCZĄTKU
}

Człowiek wkracza w dramat prawdy i nieprawdy, gdy napotyka nieprawdę - doświadczenie braku prawdy, nieprawdy, jest pierwsze, dopiero potem przychodzi pytanie o prawdę. Ale, gdzie szukać źródłowego doświadczenia nieprawdy? Są dwie możliwości: albo w obszarze doświadczeń świata-sceny ludzkiego dramatu, albo w obszarze doświadczeń dialogicznych, a więc na linii Ja i inny człowiek. W pierwszym wypadku źródłową nieprawdą byłoby szeroko pojęte złudzenie, w drugim byłoby nią kłamstwo. Jeśli tak, rodzi się nowe pytanie: która nieprawda jest bardziej podstawowa? Filozofia klasyczna nie daje na to pytanie jednolitej odpowiedzi. Najczęściej wskazuje na złudzenia świata, co jednak nie umniejsza znaczenia drugiej odpowiedzi.

Przykładem pierwszej odpowiedzi jest koncepcja Platona. Słynna metafora jaskini, która w obrazowy sposób przedstawia początek myślenia filozoficznego, zakłada, że właściwym przeciwieństwem prawdy są złudzenia. Złudzena pojawiają się na linii stosunku intencjonalnego człowieka-myśliciela do świata-sceny. Przykuty kajdanami do skały człowiek, ogląda jedynie cienie prawdziwej rzeczywistości, która rozpościera się poza jego plecami. Aby dojść do prawdy, trzeba szczególnego wysiłku - trzeba oderwać się od danych zmysłowych, odwrócić ciało nie bacząc na ucisk kajdan, zaufać temu, co mówi rozum. Prawda nie jest sprawą zmysłów, lecz rozumu. Kto wierzy wyłącznie zmysłom, nigdy nie pozbędzie się złudzeń. Rozum, zmierzając do prawdziwego, pozazjawiskowego świata, daje się prowadzić intuicją istotnego związku między złudzeniem a rzetelnym przejawem rzeczy: złudzenie jest możliwe wyłącznie $\mathrm{w}$ ramach rzetelnego przejawiania się czegoś jako integralna część składowa owego przejawiania. Innymi słowy: złudzenie to skrzywienie zjawiska. Stąd zadaniem rozumu, który ma moc sądzenia w oparciu o własne kryteria, jest wskazanie na granicę między złudzeniem a rzetelnym przejawem. Celowi temu służy pojęcie istoty. Czymże bowiem jest istota? Jest tym, co mimo zmienności i różnorodności doświadczeń potwierdza się jako stale obecne i w tym potwierdzaniu wykazuje swój nie możliwy do przekreślenia udział w prawdzie bytu. Jak wiadomo, do platońskiego pomysłu nawiąże potem E. Husserl, rozwijając koncepcję fenomenologii eidetycznej. Fenomenologia ta jest próbą opisu doświadczenia świata na poziomie, na którym nie są 
już możliwe żadne złudzenia - na poziomie czystych fenomenów i ich istot. I choć opisywany przez fenomenologię eidetyczną świat jest w zasadzie tożsamy $\mathrm{z}$ platońskim światem cieni, to jednak fenomenologia, która umie nawet $\mathrm{w}$ cieniach wypatrzeć blask słońca, nie jest żadnym cieniem nauki, lecz nauką rzetelną.

$\mathrm{Na}$ początku czasów nowożytnych jednak pojawia się inny wybór i inna droga. Ojcem nowego wyboru jest Kartezjusz. Rozpoczyna on, jak wiemy, od wątpienia we wszystkie prawdy, co do których istnieje choćby cień wątpliwości. Kartezjusz radzi sobie bez trudu z prawdami zmysłów; zmysły często nas łudzą a temu, kto choć raz wtrącił nas w nieprawdę, nie należy nigdy do końca wierzyć. Większą trudność sprawiają mu prawdy rozumu. Aby podważyć także te prawdy, filozof wysuwa słynną hipotezę „,złośliwego geniusza”. Czytamy: „Przyjmuję więc, że nie najlepszy Bóg, źródło prawdy, lecz jakiś duch złośliwy a zarazem najpotężniejszy i przebiegły, wszystkie swe siły wytężył w tym kierunku, by mnie zwodzić. Będę uważał, że niebo, powietrze, ziemia, barwy, kształty, dźwięki i inne rzeczy zewnętrzne są tylko zwodniczą grą snów, przy pomocy których zastawił on sidła na mą łatwowierność. Będę uważał, że ja sam nie mam ani rąk, ani oczu, ani ciała, ani krwi, ani żadnego zmysłu, lecz że mylnie sądziłem, iż to wszystko posiadam”. A nieco wcześniej: „Skąd wiem, że tak jak o innych niekiedy sądzę, że się mylą w takich sprawach, o których - jak im się wydaje - posiadają doskonałą wiedzę, że tak samo ja sam nie ulegam złudzeniu, gdy dwa do trzech dodaję lub licze boki kwadratu, albo gdy wykonuję jeszcze coś łatwiejszego, jeśli coś takiego da się pomyśleć? A może Bóg nie chciał, bym był tak oszukiwany? Nazywa się przecież największą dobrocią. Lecz jeśliby się to nie zgadzało z Jego dobrocią, by mnie stworzył takim, iżbym się zawsze mylił, to zdawałoby się, że ta sama dobroć nie pozwala na to, bym się tylko czasem mylił. A tego faktu nie można zaprzeczyć" ${ }^{1}$. Hipoteza złośliwego demona w miejscu Boga zmienia gruntownie sens pojęcia prawdy podstawowej: prawdą podstawową i pierwszą nie jest przeciwieństwo złudzenia, lecz przeciwieństwo kłamstwa. Poszukujący prawdy myśliciel nie ma już do czynienia ze skończonością swych władz poznawczych, które sprawiają, że z każdym przejawem miesza się jakieś złudzenie, ale ze stojącym na zewnątrz, sprytnym i potężnym kłamca.

Wniknijmy głębiej w sens kartezjańskiej metafory. Rozważmy bliżej jej założenia i horyzonty, które otwiera przed myśleniem.

Hipoteza złośliwego demona sugeruje nam, że nieprawda tworzona przez kłamstwo przenika w duszę głębiej niż nieprawda tworzona przez zmysły. Kłamca może nam „wmówić” nieprawdę, z której nie jest nas

1 R. Descartes, Medytacje o pierwszej filozofii, Warszawa 1958, s. 28, 26. 
w stanie wyprowadzić żaden zmysł ani wszystkie zmysły razem wzięte. Dlaczego? Dlatego, ponieważ kłamstwo dotyczy bezpośrednio sprawy istnienia lub nieistnienia przedmiotu, rzeczy, człowieka, Boga, podczas gdy iluzja zmysłów jest w stanie ogarnąc jedynie obszar danych jakościowych i ewentualnie ilościowych, nie tykając sprawy istnienia. Można mieć wątpliwości, czy woda, do której wsadzam rękę, jest ciepła czy zimna, niebieska czy zielona, płytka czy głęboka, ale nie ma wątpliwości, że ona jest - jest, jak moja ręka. Samo pytanie o to, jaka jest woda, zakłada, że woda jest. Zakładają to również wszystkie wysuwane na to pytanie odpowiedzi. Pasywność poznań zmysłowych tym się między innymi charakteryzuje i przejawia, że doznania te muszą obracać się stale w obszarze tego, co dane i zadane. A to, co dane i zadane, - jest. Wpatrując się $\mathrm{W}$ to, co mówią zmysły, nie mamy powodów do radykalnych wątpliwości. Nigdy nie dojdziemy do wniosku, że to, co widzimy, jest tylko cieniem. Platoński kajdaniarz, aby taki wniosek wyprowadzić, musiał oderwać się od zmysłów, zadać sobie ból, odwrócić się i porównać widok z przodu z widokiem, który uzyskał odwracając się poza siebie.

Sytuacja zmieni się jednak radykalnie, gdy przyjdzie do mnie ktoś inny i powie: tu nie ma żadnej wody, twoja ręka nie jest twoją ręką, cała wymowa świata jest jednym wielkim kłamstwem - kłamstwem, które mówi kłamliwy Bóg. Słowa kłamcy przenikają głębiej, dotykaja podstawowego sensu, w ramach którego może dopiero przebiegać zmysłowe doświadczenie, podważają ontologiczne podstawy owego doświadczenia. Jeśli bowiem to, co dla mnie jest wodą, nie jest wodą dla innych, nie jest też wodą naprawdę. Jeśli woda, którą piję, nie istnieje dla innych ludzi, nie powinna równièż istnieć dla mnie. Innymi słowy: pytanie o jakości doświadczenia zmysłowego jest pytaniem o charakterze monologicznym, pytanie o istnienie jest pytaniem dialogicznym. Przeświadczenia uzyskane na drodze dialogicznej zapadają głębiej niż przeświadczenia monologiczne. Głębsze są również odnośne wątpliwości.

Stając wobec złośliwego demona, który ma w rękach wszelkie narzędzia kłamstwa, musimy zdobyć się na niezwykłą czujność. Być może, aby nas zwieść, przedstawi się on nam w blaskach nadziemskiego piękna przemówi do nas nie tylko obrazem, ale również poetyckim, zwodniczym słowem. Piękno, mówił Kant, jest ,symbolem dobra”. Ale nam nie będzie wolno wierzyć temu pięknu. Być może pojawi się jako nasz dobrodziej, z obietnicą szczęścia na ustach. Nam jednak nie będzie wolno uwierzyć w tę obietnicę. Jesteśmy zobowiązani do radykalnego krytycyzmu. Wciąż musimy pytać, co naprawdę jest? Powstaje jednak trudność: skoro nasze wątpliwości mają charakter dialogiczny, czy wystarczy nam do ich przezwyciężenia pewność o charakterze monologicznym? Czy w namyśle nad samym sobą mogę odzyskać to, co straciłem w rozmowie z innym? Odpo- 
wiedź Kartezjusza brzmi: nie. Dlatego naszym zadaniem podstawowym staje się osiągnięcie stanu niekłamanej prawdomówności, jaka jest możliwa wyłącznie $w$ rozmowie $z$ Bogiem. Stąd znaczenie, jakie nabiera $u$ Kartezjusza sprawa istnienia Boga.

Dotykamy tutaj istotnej dla filozofii dialogu sprawy punktu wyjścia myślenia i kierunku, jaki winno ono obrać od samego początku. Zadaniem podstawowym jest: przezwyciężyć niepewność dialogiczną. Co jest podstawą umożliwiającą to przezwyciężenie? Podstawą jest uznanie istotnego związku między prawdomównością a kłamliwością, analogicznego do związku zachodzącego między złudzeniem a rzetelnym przejawem. Pamiętajmy, że aby mogło pojawić się złudzenie, musi u jego podstaw znaleźć się rzetelny przejaw czegoś; podobnie tutaj: aby możliwe było kłamstwo, u jego podłoża musi znaleźć się prawdomówność. Złudzenie jest możliwe wyłącznie $\mathrm{w}$ horyzoncie otwartym przez rzetelną intuicję istoty zjawiska. Stąd pytanie: jakiej prawdomówności potrzeba złośliwemu demonowi, by możliwe stało się jego kłamstwo? Którędy przebiega granica między kłamstwem a prawdomównością, wytyczona przez samo kłamstwo?

Najpierw sam Kartzjusz zwraca uwagę na granicę ustanowioną przez istnienie: ,...istnieje zwodziciel..., który zawsze rozmyślnie mnie łudzi. Nie ma więc wątpliwości, że istnieję, skoro mnie łudzi! I niechajże mnie łudzi, ile tylko potrafi, tego jednak nigdy nie dokaże, aby był niczym dopóty, dopóki będę myślał sam, że czymś jestem" "2. Żadne więc kłamstwo nie może posunąć się tak daleko, by zniszczyć przeświadczenie o istnieniu mnie samego - tego ,ja”, które dla kłamliwego ducha jest ,ty”. Ten punkt poglądów Kartzjusza spotkał się z wieloma krytykami, podlega też rozmaitym interpretacjom. Nie wchodząc w szczegóły zagadnienia, zwróćmy uwagę jedynie na to, co podstawowe: Kartezjusz nie głosi poglądu, że w samowiedzy mojego „ja” nie ma złudzeń, że nie mogę się mylić co do tego, jaki jestem, jaki mam charakter, jakie postawy życiowe, jakie emocjonalne napięcia mną rządzą. Jego sąd dotyczy wyłącznie istnienia „,ja”. Przeświadczenie o istnieniu „mnie samego” jest nie do podważenia, ponieważ sam kłamca jest jego współtwórcą. Kłamca nie tylko potwierdza istnienie okłamanego, lecz on je wręcz ustanawia: gdy wiem, że moje ,ja” stało się „ty” dla złośliwego kłamcy, tym pewniej wiem, że jestem — ja jestem. Kłamca, okłamując mnie, odebrał mi być może świat, ale przywrócił mi siebie. Okłamani istnieją jakby „mocniej” niż przemilczani.

Kartezjusz mówi: „...dopóki będę myślał sam, że czymś jestem”. Czy

2 Tamże, s. 31. 
znaczy to, że gdy myśleć przestanę, to przestanę też być? Albo, że gdy tylko pomyślę sobie, że mnie nie ma, to naprawdę mnie nie będzie? Sens wypowiedzi nie jest całkiem jasny, aczkolwiek jej intencja wydaje się dość wyraźna. Odnajdując w sobie obszar zakreślony doświadczeniem istnienia ,,ja”, odnajduję zarazem obszar wolny zarówno od złudzeń jak od kłamstw. E. Husserl nazwie później ten obszar obszarem spostrzeżenia immanentnego. Nie są tu możliwe żadne złudzenia, ponieważ spostrzeżenia, które tu się dokonują, dokonują się bez pośrednictwa zjawisk. Złudzenia zaś są możliwe jedynie tam, gdzie są zjawiska. Obszar ten jest również odporny na wszelkie zakłamania. Kłamstwo zawiera bowiem w sobie intencję potwierdzającą istnienie okłamywanego. Tak więc mimo że obracamy się w kręgu nieprawdy - pojętej czy to jako złudzenie, czy jako kłamstwo - stoimy na mocnym gruncie istnienia.

Inną granicą kłamstwa jest prawdomówność samego kłamcy w dialogu z sobą. Przenieśmy się w głąb jego duszy i zwróćmy uwagę na intencje, które przenikają myślenie nastawione na okłamywanie innych. Myśleniem tym kieruje potrójna intencja: jeden jej promień kieruje się na innego człowieka - tego, kogo trzeba okłamać; drugi promień zatrzymuje się na prawdzie, którą trzeba ukryć; promień trzeci obejmuje mowę, która „,przekłada” prawdę na kłamstwo tak, by kłamstwo wyglądało jak prawda. Aby kłamstwo wypadło przekonująco, kłamca musi wiedzieć, kim jest i jaki jest człowiek, którego zamierza okłamać, jaką prawdę należy przed nim ukryć i jakie odstępstwo od prawdomówności jest konieczne, by wyglądało jak prawdomówność. Dialogowi kłamstwa musi skrycie towarzyszyć drugi dialog - dialog prawdomówności, z tą jednak różnicą, że pierwszy jest dialogiem z innym, a drugi wewnętrznym dialogiem kłamcy z samym sobą.

Należy jeszcze powiedzieć o aksjologicznych granicach kłamstwa. Kłamie ten, kto nieprawdę podaje jako prawdę. Kłamca nie przeczy temu, że prawda jest wartością. Wręcz przeciwnie, on tę wartość uznaje i potwierdza. Kłamstwo nie jest zaprzeczeniem wartości prawdy, lecz jej udawaniem. Skoro tak, wyłania się potrzeba jakiegoś usprawiedliwienia odstępstwa od wartości, którą się uznaje. Prawdomówność takich usprawiedliwień nie potrzebuje, ponieważ jest wartością jakby przez się zrozumiałą. Nie pytamy - poza wyjątkowymi okolicznościami - dlaczego ktoś mówi prawdę, pytamy natomiast, dlaczego i po co kłamie.

W tym punkcie warto odwołać się do poglądów F. Nietzschego. Nietzsche, jak wiemy, dokonuje swoistego ,przewrotu” w dziedzinie wartości. wynosząc wartości witalne ponad wartości duchowe, do których należą również wartości poznawcze. Sądzi on, że kłamstwo służące życiu jest wartością wyższą niż prawda. Pogląd taki nie jest dla samego Nietzschego oczywisty, lecz wymaga wyjaśnień, usprawiedliwień. Nietzsche próbuje 
to uczynić. Pisze: „Fałszywość jakiegoś sądu nie jest jeszcze dla nas przeciw sądowi temu zarzutem; w tym nowość mowy naszej brzmi snadź najniezwyklej. Chodzi o to, o ile wpływa on na wzmożenie życia, na utrzymanie gatunku, może nawet na chów gatunku; i zasadniczo skłaniamy się do stwierdzenia, iż najfałszywsze sądy (do których należą sądy syntetyczne a priori) są dla nas najniezbędniejsze, iż odmawiając znaczenia fikcjom logicznym, nie mierząc rzeczywistości miarą li zmyślonego świata Absolutu, Równemu-sobie-samemu, nie fałszując liczbą nieustannie świata, człowiek nie mógłby żyć, - że wyrzeczenie się fałszywych sądów byłoby wyrzeczeniem się życia, zaprzeczeniem życia. Uznać nieprawdę warunkiem życia: znaczy to wprawdzie w niebezpieczny sposób stanąć okoniem przeciwko nawykowym względem wartości uczuciom; zaś filozofia, która

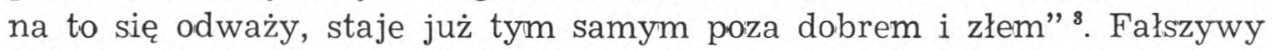
sąd nie jest więc wartością samą w sobie, ale nabiera wartości dzięki życiu, któremu służy. Można się domyślać, że inaczej ma się sprawa z prawdą i prawdomównością: te są wartościami przez się a jeśli z jakichś powodów i dla kogoś jest inaczej, wymaga to odrębnych uzasadnień, które nie wszystkich przekonują.

Powróćmy jednak do metafory Kartezjusza i perspektyw, jakie otwiera przed myśleniem.

Z tego, co powiedziałem, wynika, że w metaforyce kartezjańskiej znajdują się zaczątki filozofii dialogu. Myślenie filozoficzne, czyli myślenie radykalne, jest możliwe wyłącznie jako spór z kłamcą a nie jako rozjaśnianie i przekraczanie samych tylko złudzeń zmysłowych. Kłamstwo złośliwego geniusza przenika głębiej niż złudzenia, ponieważ narusza przeświadczenia o istnieniu rzeczy i świata. Nie ma przy tym decydującego znaczenia to, czy złośliwy geniusz naprawdę istnieje, czy nie, ponieważ demon możliwy odgrywa w poznaniu taką samą rolę jak demon rzeczywisty. Przyjąwszy, że uniwersalne kłamstwo jest możliwe, otwieramy drzwi dla rzeczywistych wątpliwości. Myślenie pojęte jako dialog z kłamcą potrzebuje jednak pewnych założeń, które określą horyzont jego rozwoju. Założeniem podstawowym jest idea absolutnej prawdomówności Boga, będąca przeciwieństwem idei demonicznego kłamcy. Skąd bierze się taka idea? Gdzie tryska jej źródło?

Załóżmy więc: istnieje potężny kłamca, który mnie okłamuje we wszystkim, w czym tylko potrafi. Musi to być kłamca przebiegły, który dobrze zna przebiegi poznań i sposoby powstawania przeświadczeń z poznaniem związanych. Kłamca ten wciąż musi „wczuwać się" w to, co myślę i co przeżywam, musi stawać na moim miejscu, by widzieć świat moimi oczami. Innymi słowy: musi stosować swoje kłamstwo do prawdy,

${ }^{3}$ F. Nietzs che, Poza dobrem $i$ złem, Warszawa 1917, s. 4. 
która odsłania się przede mną, aby ją następnie móc przezwyciężyć. Nie może jednak robić tego inaczej, jak odtwarzając w sobie cały mój proces dochodzenia do prawdy. Nie można przecież kłamać, jeśli się samemu nie zna prawdy. Kto głosi nieprawdę, nie znając prawdy, ten się myli, ale nie kłamie. Skoro złośliwy demon kłamie, musi znać prawdę. Aby mnie okłamać, nie może okłamywać siebie. Kłamiąc na zewnątrz, musi być prawdomówny do wewnątrz. Musi więc prowadzić sam z sobą dialog absolutnej prawdomówności, jaki prowadziłby ze mną, gdyby mnie nie chciał okłamywać. Raz jeszcze okazuje się więc, że prawda i prawdomówność są pierwsze, bardziej podstawowe a kłamstwo wtórne.

Uznając jednak radykalne pierwszeństwo prawdomówności przed kłamstwem, uznajemy zarazem pierwszeństwo idei prawdomównego Boga, który jest podmiotem prawdziwego poznania i wszelkiej prawdomówności przed ideą kłamliwego demona. Idea prawdomównego Boga nie bierze się jednak z nikąd. Wyłania się ona $\mathrm{z}$ duszy samego kłamcy, który kłamiąc, musi ją mieć w sobie i musi ją w sobie potwierdzać. Kartezjusz widzi to doskonale. Jego argumenty na istnienie Boga nie są niczym innym jak rozwinięciem tezy o pierwszeństwie prawdomówności przed kłamstwem. Ukazują one, że kłamstwo jest możliwe wyłącznie w horyzoncie jakiejś prawdomówności. Ujawniają nadto jeszcze jeden ważny wymiar myślenia: myślenie nie jest tylko czyimś myśleniem i myśleniem o czymś, ale jest również myśleniem ,wobec kogoś" — wobec tego mianowicie, kto ustanawia dla niego udział absolutnej prawdomówności.

\section{ZWEI METAPHERN DER ANFANGE}

\section{Z u s a m enf as sung}

Der Autor stellt Betrachtungen über zwei Metaphern der Anfänge des philosophischen Denkens an, aufgefaßt als ein Drama der Wahrheit: die Metapher Platos, die die Menschen in einer Schattenhöhle, und die Metapher des Cartesius, die den Streit des Denkers mit dem Lügner-Dämonen beschreibt. Der ersten Metapher nach hat des die Wahrheit suchende Denken vor allem mit Sinnestäuschungen zu tun, der zweiten Metapher nach dagegen mit der Lüge. Welches Denken ist fundamentaler und damit philosophischer? Da die Lüge tiefdringender ist als die Täuschung, da sie nicht nur die Sinne sondern auch den Verstand ergreift, ist der Streit mit der Lüge fundamentaler. Die Metapher des Cartesius erschließt somit dem Denken tiefere und weitere Horizonte, verleiht diesem Denken dialogischen, tiefgehenderen Charakter.

Indem der Autor davon ausgeht, daß die eigentliche Aufgabe des philosophischen Denkens die Auseinandersetzung mit der möglichen Lüge der Welt ist, stellt er 
die Frage, ob die universale und nadikale Lüge möglich sei, in der die gänzliche Verwerfung der Wahrheit erfolgte. Die Antwort ist negativ. Die Lüge ist ja ausschließlich im Bereich der fundamentaleren Wahrhaftigkeit möglich. Die Lüge ist keine Verwerfung der Wahrheit, sondern deren Schein. Damit ein Dialog der Lüge zwischen dem Lügner und den Belogenen möglich wäre, müßte ein paralleler Dialog des Lügners mit sich selbst bestehen, der unmöglich ein Dialog der Lüge sein kann, sondern im Gegenteil ein Dialog der Wahrheit sein muß. Der Dialog der Wahrhaftigkeit ist fundamentaler, er bedingt die Lüge, und nicht etwa umgekehrt. Der Dialog der absoluten Wahrhaftigkeit wäre jedoch nicht möglich, wenn ihn nicht die Idee des Wesens Gottes bedingte, das die Wahrheit kennt und die Wahrheit kündet. Daher kommt bei Cartesius die besondere Art von Argumenten für das Sein Gottes. Gott ist hier vor allem die von der Wahrhaftigkeit vorausgestetzte Idee. Dank dieser Idee enthüllt das philosophische Denken noch eine Dimension - es wird zum Denken ,,jemandem gegenüber”. 